\title{
The Reno-Protective Effects of Coconut Water on the Kidneys of Diabetic Wistar Rats
}

\author{
Eze K. Nwangwa
}

Department of Physiology, College of Health Science, Delta State University, P.M.B. 001 Abraka, Nigeria

\begin{abstract}
Diabetes Mellitus is one of the leading causes of end stage renal failure. In this present study the remedial effect of coconut water on alloxan-induced diabetes mellitus on the total body weight, kidney function and kidney cyto-architecture were studied. A total of eighteen (18) wistar rats were randomly divided into three experimental groups $(\mathrm{n}=6)$. Group I (Control) was fed on rat chow and water ad libitum and Group II and III were made diabetic by single intra peritoneal dose of $150 \mathrm{mg} / \mathrm{kg}$ body weight of alloxan monohydrate. Group II were fed rat chow and water ad libitum and Group III fed a rat chow and coconut water ad libitum for 30 days. The result showed a statistical significant $(\mathrm{P}<0.05)$ reduction in weight, a significant increase in the renal function parameters (urea, creatinine, potassium, sodium and bicarbonate) due to diabetes and a significant reduction in these parameters following the administration of coconut water. The renal cyto-architecture also showed a protective/regenerative effect following treatment with coconut water. This finding may be beneficial in preventing kidney damage in diabetic patients.
\end{abstract}

Keywords Renal Histology, Renal Function Test, Coconut (Cocos Nucifera) Water

\section{Introduction}

According to the American Diabetes Association (ADA) (2004), diabetes is a metabolic disease caused by excess glucose in the blood and is characterized by hyperglycemia resulting from defects in insulin secretion, action or both. In diabetes the level of blood glucose is persistently raised above normal range [80 - 100]mg/dl, (Peter et al, 1996). Uncontrolled diabetes mellitus causes varied histopathological changes in different organs (Harold, 1978; Thomas, 1999) and incidences of diabetic nephropathy has been on the increase (Adewole et al., 2006; Carrington and Litchfield, 1999; Clements and Bell, 1982).

Coconut water, an isotonic beverage with the same level of electrolyte balance as that of human blood, was regularly used to give emergency plasma transfusion to wounded soldiers in the pacific war (Campbell - Falck et al, 2000). It has less sodium (25mg) than energy drinks (200mg) and sport drinks (41mg), it is very high in chloride at $118 \mathrm{mg}$ compare to $38 \mathrm{mg}$ of sport drinks (George et al., 2004). According to Bruce (2000), coconut water contains $95.3 \%$ water, $0.005 \%$ nitrogen, $0.56 \%$ Phosphoric acid, $0.25 \%$ Potassium, 0.69\% Calcium Oxide, 0.59\% Magnesium Oxide, $0.5 \%$ Iron, $0.8 \%$ reducing sugar and a total sugar of $2.08 \%$.

Coconut water is more nutritious than whole milk for its

* Corresponding author:

drezekingx@yahoo.com (Eze K. Nwangwa)

Published online at http://journal.sapub.org/health

Copyright $(\underset{2}{ } 2012$ Scientific \& Academic Publishing. All Rights Reserved less fat and no cholesterol, more healthy than orange juice for it is much lower calories and better than processed baby milk as it contain lauric acid which is present in human mother's milk (George et al., 2004). Coconut water is used as therapeutic means of fighting against viruses (Ranti et al, 1965), it also replenishes the body's fluid after exercise, lowers cholesterol, re-hydrates the body and can carry nutrients and oxygen to cells (Thomas et al, 2000).

According to Campbel-falck (2002), coconut water contains organic compound posing healthy growth promoting properties that have been enough to help treat kidney and urethral stones. Nigerian researchers of the faculty of basic medical sciences, university of Illorin examined the blood sugar lowering effect of coconut water, extracted from Picralima nitida seed. In conclusion it was shown that coconut water extracted of $\mathrm{P}$. nitida seed have a significant hypoglycemic (lowering) effects in alloxan induced diabetes (Salihu et al, 2009).

The aim of the present study therefore, is to investigate the effect of administration of coconut water on the renal function and histology in alloxan-induced diabetic wistar rats.

\section{Materials and Methods}

\subsection{Animals and Animal Handling}

Eighteen (18) adult rats of the Wister strain weighing between $170 \mathrm{~g}-180 \mathrm{~g}$ of both sexes were used and these rats were purchased from the Animal Centre Benin City, Edo State, Nigeria. They were housed individually, in special 
clear-sided cages of same sizes at the Animal Centre of the Faculty of Basic Medical Sciences, Delta State University, Abraka for 14 days acclimatization and duration of the experiment. The rats were kept at room temperature and humidity and were given rats chow and water ad libitum. The coconut water was gotten from coconut fruits bought from Ubulu-uku market, Ubulu-uku in Delta State. The coconut fruit was authenticated in the department of Botany, Delta State University, Abraka, Nigeria.

\subsection{Induction of Diabetes}

Diabetes was induced by a single intraperitoneal administration of freshly prepared solution of alloxan monohydrate $(150 \mathrm{mg} / \mathrm{kg})$ (Pari and Mahesulari, 1999), and 5 days later, one touch glucometer (Lifescan Johnson and Johnson, Carlifonia) was used to confirm diabetes using blood samples collected from the tails of the rats at blood glucose level $\geq$ $250 \mathrm{mg} / \mathrm{dl}$.

\subsection{Experimental Design}

The rats were randomly divided into three experimental groups $(\mathrm{n}=6)$. Group I (Control) was non diabetic fed on normal rat chow and water ad libitum. Groups II and III were diabetic fed on normal rat chow plus water ad libitum and normal rat chow plus coconut water ad libitum respectively. All administration of water, coconut water and rat chow was between the hour of $8 \mathrm{am}$ and $6 \mathrm{pm}$ which lasted for the duration of 30 days.

\subsection{Tissue Processing/Photomicrography}

The rats were sacrificed after thirty days and their kidney harvested, observed microscopically fixed in formal saline and then prepared for tissue photomicrograph.

\subsection{Statistical Analysis}

All data were expressed as mean \pm SD (Standard Deviation).The results were analyzed by one-way analysis of variance (ANOVA), followed by comparison between test and control groups using Student's t-test. Differences between groups were considered significant at $\mathrm{p}<0.05$.

\section{Results}

Table 1. Change in Body Weight of Rats (g)

\begin{tabular}{cccc}
\hline \multirow{2}{*}{ Groups } & $\begin{array}{c}\text { Initial } \\
\text { Weight }(\mathrm{g})\end{array}$ & $\begin{array}{c}\text { Final Weight } \\
(\mathrm{g})\end{array}$ & $\begin{array}{c}\text { Weight Difference } \\
(\mathrm{g})\end{array}$ \\
\hline I & $173 \pm 2.18$ & $175 \pm 2.01$ & $2 \pm 0.17$ \\
II & $171 \pm 2.49$ & $132 \pm 2.86^{*}$ & $39 \pm 0.37^{*}$ \\
III & $180 \pm 3.27$ & $139 \pm 2.10^{*}$ & $41 \pm 1.27^{*}$ \\
\hline
\end{tabular}

Values are presented as means $\pm \mathrm{SD} ; * \mathrm{P}<0.05$ compared with group I; $+\mathrm{P}<0.05$ compared with group II; Group abbreviations as in table.

Table 1 shows the weight of wistar albino rats of normal control, diabetic and diabetic treated rats. The mean final weight of group II, diabetic rats show a significant $(\mathrm{P}<0.05)$ reduction in body weight when compared with the control group. Also observed is a significant $(\mathrm{P}<0.05)$ reduction in weight in group III compared with normal control (Group I). No significant difference was observed between Group III and Group II.

Table 2. Changes in Renal function parameters

\begin{tabular}{cccc}
\hline Parameters & Group I & Group II & Group III \\
\hline Urea (mmol/L) & $1.9 \pm 0.25$ & $2.5 \pm 0.42^{*}$ & $2.0 \pm 0.21$ \\
Creatinine & $42 \pm 2.11$ & $58 \pm 2.04^{*}$ & $49 \pm 9.41$ \\
$(\boldsymbol{\mu m o l} / \mathbf{L})$ & $80 \pm 4.16$ & $101 \pm 3.11^{*}$ & $98 \pm 4.11^{*}$ \\
$\mathbf{N a}^{+}(\mathbf{m m o l} / \mathbf{L})$ & $6.6 \pm 0.91^{*}$ & $4.2 \pm 0.02$ \\
$\mathbf{K}^{+}(\mathbf{m m o l} / \mathbf{L})$ & $3.5 \pm 0.71$ & $18 \pm 2.45^{*}$ & $13 \pm 2.41$ \\
$\quad \mathbf{H C O}$ & $12 \pm 2.04$ & & \\
$(\mathbf{m m o l} / \mathbf{L})$ & &
\end{tabular}

Values are presented as means $\pm \mathrm{SD} ; * \mathrm{P}<0.05$ compared with group I; $+\mathrm{P}<0.05$ compared with group II; Group abbreviations as in table.

Table 2 shows a significant $(\mathrm{P}<0.05)$ increased level in all the parameters (Urea, Creatinine, Sodium, Potassium, and Bicarbonate) in Group II (diabetic rats) compared with Group I (Control) and significant $(\mathrm{P}<0.05)$ reduction in levels of Urea, $\mathrm{K}^{+}$and $\mathrm{HCO}_{3}{ }^{-}$in Group III (treated with coconut water) compared with Group II.

\subsection{Microscopic Examination of the Kidney}

Plate 1 (Group 1) - normal control) shows the intact Bowman's capsule. The glomerulus (A) contains cells with tuft of capillaries. The distal convoluted tubules show normal outline. The proximal convoluted tubules show single cuboidal epithelial cells with normal cellular structure (B) with normal interstitial space (C).

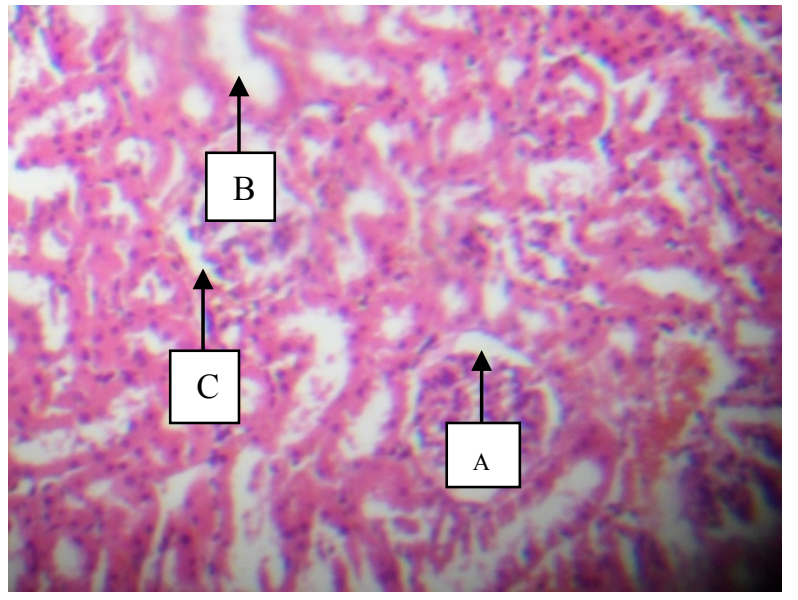

Plate 1. showing Glomerulus (A), Tubules (B) and interstitial space (C) $(\mathrm{H} \& \mathrm{E}, \mathrm{x} 100)$

Plate 2 (Group 2) - diabetic induced rats) shows some degeneration of the glomerulus, with sparsely distributed cells with tuft capillaries the distal convoluted tubules show sparsely distributed cells. The proximal convoluted tubules are well outlined with few single cuboidal epithelial cells.

Plate 3 (Group 3) - diabetic rats treated with coconut water) shows intact Bowman's capsule. There were multiple glomeruli containing densely packed cells with tuft capil- 
laries. The distal convoluted tubules show normal outline. The proximal convoluted tubules show single cuboidal epithelial cells with normal cellular structure.

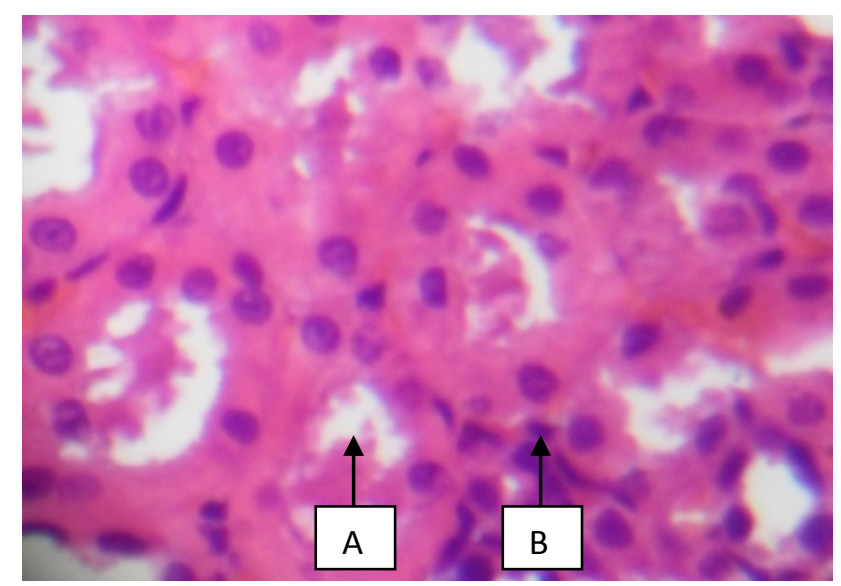

Plate 2. Showing Tubular Protein cast (A), and chronic inflammation with fibrosis (B) (H \& E x10)

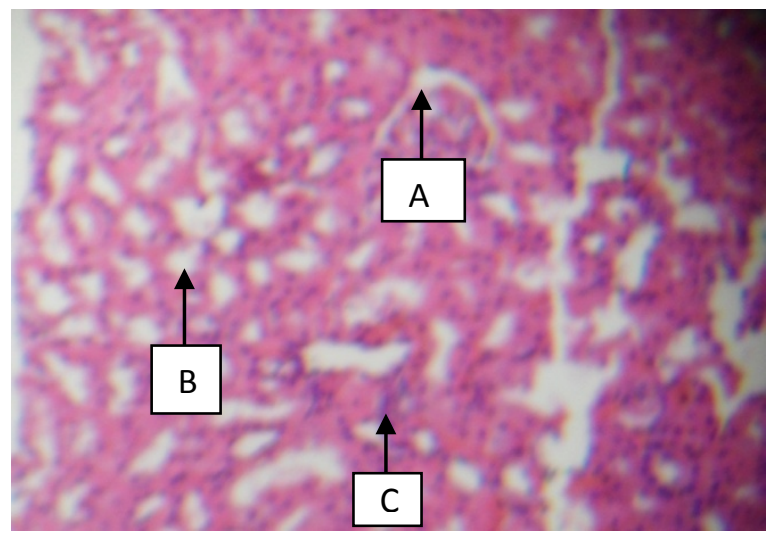

Plate 3. showing Glomerulus (A), Tubules (B) and Interstitial Space with mild inflammation $(\mathrm{C})(\mathrm{H} \& \mathrm{E}, \mathrm{x} 100)$

\section{Discussion}

The result from this present study shows that diabetes mellitus causes a significant $(p<0.05)$ reduction in the body weight of rats as shown in Group II compared with Group I (Control) rats and concomitant administration of coconut water did not cause any significant difference in the weight. This finding is contrary to the report of Loperito and Rajamohan (2003) who reported that coconut water causes a further decrease in the weight of diabetic rats. Weight loss is a well documented clinical feature of diabetes mellitus which may be due to degeneration of the adipocytes and muscle tissues to produce energy and over conversion of glycogen to glucose (Reno and Lekerd, 1999; Zink and Chaffin, 1998)

There is also a significant $(\mathrm{P}<0.05)$ increase in the levels of urea $(2.5 \pm 0.42 \mathrm{mmol} / \mathrm{L})$, Creatinine $(5.8 \pm 2.04 \mu \mathrm{mol} / \mathrm{L})$, sodium $(101 \pm 3.11 \mathrm{mmol} / \mathrm{L})$, Potassium $(6.6 \pm 0.91 \mathrm{mmol} / \mathrm{L})$ and Bicarbonate $(18 \pm 2.45 \mathrm{mmol} / \mathrm{L})$ in diabetic non treated rats (Group II) compared with the Control (Group I) and treatment with coconut water (Group III) caused a significant $(\mathrm{P}<0.05)$ reduction in urea $(2.0 \pm 0.21 \mathrm{mmol} / \mathrm{L})$, potassium
$(4.2 \pm 0.52 \mathrm{mmol} / \mathrm{L})$ and bicarbonate $(13 \pm 2.41 \mathrm{mmol} / \mathrm{L})$ compared with Group II. This further explains the destructive effects of diabetes mellitus on the kidney with the resultant increased incidence in diabetic nephropathy (Collier et al, 2006).

The histology of the kidney of the Control (Group I) shows glomerulus with normal capillaries with the Distal Convoluted and Proximal Tubules showing normal cellular structures compared with that of diabetic rats (Group II) which shows some degeneration of the glomerulus with presence of Tubular cast and signs of chronic inflammation. Peter et al (2006) previously reported a damaging effect of diabetes in the glomerulus thereby affecting Glomerular filtration rate (GFR). However, these findings were significantly but partially reversed by the concomitant administration of coconut water (Group III).

\section{Conclusions}

This present study shows that diabetes mellitus has a degenerative and destructive effect on the kidneys which can be partially but significantly reversed by concomitant administration of coconut water.

\section{ACKNOWLEDGEMENTS}

The researcher express his gratitude to Iyawa Onyeka for the preliminary work in this subject matter and to the staff of Chemical pathology and Histopathology Department of University of Benin Teaching Hospital for their technical support.

\section{REFERENCES}

[1] Adewole SO, Caxton-Martins EA, Ojewole JAO (2006). Histochemical and Biochemical Effects of Melatonin on Pancreatic-cells on Streptozocin -treated Diabetic Rats. Pharmacology-Online, 2: 1-21

[2] American Diabetes Association - ADA. (2004). Standards of medical care in diabetes (suppl.1): S15 - S35

[3] Bruce, F (2000) The healing miracles of coconut oil. He-wise, London p. 60

[4] Campbell - Falck, D., Thomas, T., Falck, T.M., Tutuo, N. and Clem. K. (2000). The intravenous use of Coconut water. Am. J. Emerg. Med. 18 (1): 108 - 111

[5] Carrington AL, Litchfield JE (1999). The Aldose Reductase Pathway and Non-enzymatic Glycation in the Pathogenesis of Diabetic Neuropathy: A Critical Review for the End of the 20th Century. Diabetes Rev. 7: 275-299

[6] Clements R.S, Bell D.S.H (1982). Diabetic Neuropathy: Peripheral and Autonomic Syndrome. Diabetic Neuropathy. 71: 50-67 
[7] George, A. P., Mellita K,.Ibrahim, S.S.,Bahaa, M., Ayman, S and Wolfgang, H.M. (2004).Green coconut water for intravenous use: Trace and minor element content. Journal of Trace Element in Experimental Medicine. 17:273:282

[8] Harold E (1978). Clinical Anatomy, Black Well Scientific Publication, pp. 107-109

[9] Loperito, L.A., and Rajamohan, T (2003). Hepatoprotective and antioxidant effects of coconut water on $\mathrm{CCl} 4$ - induced liver injury in rats. 40: 354-357

[10] Pari, LJ., Uma-Maheswari (1999) Hypoglycaemic effects of Musa sapientum L. in alloxan-induced diabetic rats. J.Ethnopharmacol 68:321-325

[11] Peter, J. W., Paul, L. D., Simon, L. H. (1996). Diabetes and its Management. 5th edition

[12] Ranti, IS.,Kwee, TB.,Thio, IL., and Tan, EH.,(1965). Coconut water for intravenous fluid therapy. Paediatri. Indones. 5:
$782-92$

[13] Reno, J. and. Leland, J, (1999). Heavy meddling (news). Newsweek; 134: 56-7

[14] Salihu, M. A., Luqman, A. O., Oshiba, O. J., Rabiu O. J., Sikiru A. Ji., Ayokunle O., and Adesola I. R. A. (2009). Comparative study of the hypoglycemic effects of coconut water extract of Picralima nitida seeds (Apocynaceae) and Daonil in alloxan-induced diabetic albino rats. African Journal of Biotechnology. 8 (4): 574-576

[15] Thomas PK (1999). Diabetic Peripheral Neuropathy: Their cost to the patient and society and the value of knowledge of risk factor for development of interventions. Eur. Neurol. 41: $35-43$

[16] Zink, T. and Chaffin, J. (1998). Herbal "health" products: What family physicians need to know. Am. Fam. Physician, 58: $1133-40$ 